\title{
XIV. On the decomposition of alkaline sulphurets by the oxides of lead and of manganese
}

\section{Dize}

To cite this article: M. Dize (1805) XIV. On the decomposition of alkaline sulphurets by the oxides of lead and of manganese, Philosophical Magazine Series 1, 23:89, 70-73, DOI: $10.1080 / 14786440508562484$

To link to this article: http://dx.doi.org/10.1080/14786440508562484

Published online: 18 May 2009.

Submit your article to this journal $₫$

Џ Article views: 2

Q View related articles $\widetilde{ }$ 
subioined lotion; and I am happy to announce to the pubJic, that by bathing the affected head therewith a few times, roorning aid evenung, and suffering the parts to dry without interrupion, the scabs will decorticate and peel off from the scalp, and leare the parts underneath perfectly healed; and this without torturing the patient by either shaving the head or cutting off the hair. I bave been in the habit of treating this disease in this manner, and with this application, for the last ten years, and have invariably found it to answer (when duly applied) both in children and adults; and in many inveterate cases even where every other means had been previously used without effect, some of which were of several years standing.

17. Kali sulphurat. (recens preparat.) 3 iij. Sapo, alb. Hispan. 3 js. Aq. calcis 5 vijss. Spir. vinos. rect. $3 \mathrm{ij}$.

Ft. Lotio pro tinea capitis.

Might not the above remedy for tinea capitis be efficacious in relieving that dreadful endemic disease called trichoma, or plica polonica?

XIV. On the Decomposition of Alkaline Sulphurets by the Oxides of Lead and of Manganese. By M. DizE*.

If charcoal be mixed with an alkaline sulphate, and then exposed to a high temperature, the oxycren, one of the constituent parts of the acid, burns the charcoal, quitting the sulphur which scrved as is radical; with which the alkali then combines, forming what is called an alkaline silphuret. This combination, which is a result of the decomposition of the alkaline sulphates by the charcoal, is not so easily destroyed as might be supposed, especially when large masses are operated upon. The exposure, frequently repeated, of the alkaline sulphurets to a managed heat, is not sufficient to canse the sulphur to volatilize; for the alkali still retains enough of it to render it improper for certain operations in the arts; ant the suphur during its volatilization is partly deflagrated, and forms silphurous acid, which combines with the alkali. Thus the operation is rendered more complex instead of being simplified, since we obtain only an alkali mixed with sulphuret and alkaline sulphite. 
The addition of carbonate of lime to a mixture of charcoal and alkaline sulphate, as was the practice in the tir-t manufactory of soda, established at St. Denys, near Parie, was not an expensive way of decomposing pretty speecilit. the sulphuret of soda resulting from the decomposition of the sulphate of soda by charcoal; nererthcless the soda was still contaminated with sulphuret and with sulphite of soda, which might be detected by the smell and by the crrstatlization. The substitution of iron for carbonate of lime, or these two substances employed together, gave in bettcr result. The whole of the alkali conld not be obtained pure till after repeated washings, calcinations, and crystallizations.

Such is the state of our knowlcdge of the means of purifying in the large way, and without incurring too great an expense, the alkalies which may be prepared by the decomposition of the alkaline sulphates. These difficulties, which appear of little consequence in the operations of the laboratory, become very embarrassing in large manufactories, where the results ought to be equally speedy and easy to be obtained.

Of all these processes the best is that cmployed in the manufactory of St. Denys, near Paris, and which was published at the time by order of government. This process is still the most simple, and most easy to be exccuted in the large way; at least it has been judged so according to experience. I believe that the result of my researches upon the decomposition of the sulphurets must add to its perfection, and afford some indication of which use may be made in analogous operations.

I shall not detail all the experiments which have led me to this improvement, but shall now, state the mians which I employ for decomposing the alkaline sulphurets, or frecing the soda from the last portions of sulphuret and alkaline sulphite which it contains.

After having proceeded to the decomposition of the sulphate of soda, by the mixture of charcoal and carbonate of Iime, we lixiviate the crude soda, in order to extract the alkali from it. This lixivium is commonly of a yellowish colour, and exhales the odour of sulphur: if we mix with it some drops of diluted sulphuric acid, sulphur is precipitated; and hydro-sulphurated gas and sulphurous acid are rapidly disengaged.

Were we to evaporate afterwards and crystallize this lixivium, we should obtain crystals of soda, from which diluted sulphuric acid wouid disengage hydrosulpharet and 
sulphurous acid. The rest of the liquor would give soda less pure than the first crystallization.

To purify this lixivium, and free the alkali from the sulphur which it contains in solution, and cause the sulphite to disappear, I add to the ley, while it is in ebullition, a sufficient quantity of well pulverized semi-vitreous oxide of lead. This oxide separates the sulphur from the alkali, and forms by its combination an insoluble sulphuret of lead: the sulphite disappears, and is converted into sulphate. The semi-vitreous oxide of lead loses its red colour, and assumes a deep chestnut or blackish hue, by reason of the quantity of sulphur which the alkali contains. The liquor or lixivium becomes as clear as pure water ; dilute sulphuric acid disengages from it only carbonic acid gas, and forms no precipitate: in a word, this lixivium precipitates the nitrate of lead in a white state, and the sulphate of copper is a beautiful green; whilst, prcvious to the addition of the semivitreous oxide of lead, the same lixivium precipitated these two metals of a very dark chestnut colour, that is to say, in the state of sulphuret. Thus the semi-vitreous oxide of lead, in the humid way, carries off the sulphur from the alkali of the soda, and may serve for purifying in the large way, and in a very easy manner, the soda proceeding from the decomposition of the sulphate of soda.

After these experiments, and a calculation of the expense: of the semi-vitreous oxide of lead, I substituted for it, with equal succcss, oxide of manganese well pulverized. This oxide, which is cheaper than the former, presents another alvantage: it may be employed several times for the same operation, freeing it first from the sulphur by simple calcination.

The facility with which sulphur is thus separated from soda in the humid way, without engaging it in a new combination, that is to say, leaving it isolated and dissolved in the liquid, incluced me to try the same means for decomposing sulphuret of barytes; and my attempt was attended with success.

\section{Decomposition of Sulphuret of Barytes.}

In order to obtain barytes in a caustic state, sulphate of barytes is commonly decomposed with charcoal, from which first operation results a sulphuret of barytes soluble in water: this sulphuret is decomposed with nitric acid: distillation separates the nitric acid from the barytes, and this alkali remains pure, and fixed at the bottom of the retort. This process is cxtremely expensive, un account of the large quantity 
quantity of nitric acid which it requires. Barytes will certainly become a very valuable substance for the arts, when we shall be able to procure it at a reasonable price.

The following is the most simple and the most oconomical eans which I have discovered, and which I had a long time practised for my own use.

When sulphuret of barytes is made by the decomposition of sulphate of barytes and charcoal, I dissolve it in water; after having let it settle and clear itself, I decant it into a vessel, in which I boil it, adding to it pulverized oxide of manganese, till the liquor has lost its yellow colour, and is become clear and limpid.

In proportion as the oxide of manganese separates the sulphur from the barytes, the odour of sulphur diminishes, and instead of it an alkaline odour is perceived; the taste of the liquor, when all the sulphur is combined with the manganese, has a considerable degree of causticity ; as soon as it cools, if too much water has not been employed for the solution of the sulphuret, the barytes crystallizes round the vessel.

Nitrate of lead and sulphate of copper are precipitated from their solvents by caustic barytes, the first in a white, and the second in a blue form: thus oxide of manganese has a stronger affinity with sulphur than either soda or caustic barytes has, since this oxide, at the mere degree of ebullition, decomposes these alkaline sulphurets completely. This process appeared to me simple enough to be applied to the preparation of these two alkalies upon a large scale, so as to afford them at a reasonable expense to the arts in which they may be used.

Since I first perceived that oxide of manganese attracted, in the humid way, sulphur from fixed alkalies and from barytes, this means bas been a great assistance to me in getting rid of the alkaline sulphurets in many analytical operations, in which the presence of the alkaline sulphuret embarrassed me, without my requiring an acid to decompose it.

Soda and barytes prepared by this process are very pure, and are obtained at a very moderate expense, especially barytes. 